\title{
Tectonophysics
}

T 121

CHANGES IN RADON CONCENTRATION AT BLUE MOUNTAIN LAKE, NY

A. Mogro-Campero

R. S. Likes (all at: General Electric Research and Development Center, Schenectady, NY 12301)

Radon concentration has been measured since November of 1976 at various sites on the western shore of Blue Mountain Lake, NY. This region is one of the most persistent earthquake centers in the Northeastern United States. Most of the temporal record consists of weekly readings at the bottom of $60 \mathrm{~cm}$ deep holes using the nuclear track technique to count alpha particle decays.

we have identified a small area (with scale length of a few meters) where the radon concentrations with respect to surrounding sites is: repeatedily elevated by factors of 210 to 100 . The hole with elevated radon concentration contains water whose radon content is measured. Recently an electronic detector was installed in this hole and hourly readings were recorded together with the output of a weather station operating nearby. This apparatus will be used to determine the short-term temporal behavior of the radon and assess the influence of various meteorological parameters. The day our radon monitoring began a magnitude 4 earthquake occurred about $14 \mathrm{Km}$ from our site. Since the first several months the long term radon concentration has decreased by a factor of $v 50$, during a time in which there were no earthquakes above magnitude 2 .

\section{T 122}

SEASONALLY CORRECTED RADON ANOMALIES

G. F. Birchard

F. Liboy both at: Institute of Geophysics and Planetary Physics, Univ. of California, Los

Radon concentrations measured in shallow soil holes along the San Jacinto Fault zone using Irack Etch* detectors display an annual cycle which correlates inversely with soil temperature and directly with soil moisture content. High radon concentrations existed at least two weeks before and after the largest earthquakes measured between March, 1975 and August, 1978 (the M4.7, 2 Auqust 1975, M4.3,11 August 1976, and the M4 4, 5 June 1978 earthquakes)! An the M4.4, 5 June 1978 earthquakes). An inverse relationship between the indistance of the detector from the epicenter was evident for the 11 August 1976 earthquake which was located within 1976 earthquake which was located with $4 \mathrm{~km}$. Of the nearest site. A strong trend towards higher radon concentrat from September, 1976 through August, 1978 dominates all patterns. This trend, which is probably either the result of and 1978 or the precursor of an earthquake, will be discussed.

\section{T:33}

DATA FROM THE CALTECH AUTOMATED RADON-THORON MONITORS

\section{$\frac{\text { M. H. Shapiro }}{\text { J. D. Melvin }}$}

T. A. Tombrello (all at: w. K. Kellogg Radia-

tion Lab., Caltech, Pasadena, CA 91125)

J. H. Whitcomb (Sefsmological Laboratory,

Caltech, Pasadena, CA 91125)

The Caltech automated Radon-Thoron monitors are microprocessor controlled instruments designed for field measurements of radon levels in subsurface fluids and gases for earthquake prediction research. The first prototype instrument has been in operation over a water-fille static borehole in Pasadena for more than 16 months. The instrument sanples the radon level from the borehole three times per day. Weekly averages of the data over the perfod of operation exhibit a yearly cycle that appears due to thermoelastic stresses on the environs of the borehole. Response of the instrument to nearby seismic events, and to the heavy rainfall of the 1977-1978 winter will be discussed. A second prototype instrument has been in operation for shorter period of time in a closed tunnel at Bis Dalton Canyon near Glendora. Data from this in strument show much larger short term variations than the Pasadena instrument. These variations appear to be related to local meteorological conditions, and may indicate that the site is not sufficiently decoupled from the atmosphere.

* Supported in part by the National Science Foundation [PHY76-83685] and the Caltech President's Venture Fund. †Also: Physics Department, California State
University, Fullerton, CA 92634.

T 124

ANOMALOUS CHANGES IN RADON EMANATION AND GROUND WATER QUALITY

Chi-Yu King (U. S. Geological Survey,

Five earthquakes of magnitudes between 4.0 and 4.3 have occurred within a network of radon-emanation monitoring stations in central California since the beginning of monitoring in May, 1975. This gradually expanded network now consists of more than 60 stations deployed along several mafor strike-slip faults between Santa Rosa and Cholame. These earthquakes generally Cholame. These earthquakes generally occurred during time periods when the local radon emanation was anomalously high. The radon anomalies will be described. Water level (or flow rate) and quality (temperature, conductivity and pH value) water wells and springs. Anomalous changes water wells and springs. Anomalous chan larger local earthquakes.

T 125

RADCY PRECURSOR STUDIES IN ICELAND

Eg111 Hauksson

(both at: Lamont-Dohert Geological Observatory of Columbia University, 10964)

(Selence Institute,

University of Iceland, Reykjavik, Iceland)

Current results indicate that radon anomalies which could prove useful for earthquake prediction occur prior to some earthquakes in Iceland. Sampling techniques for radon have been developed for low temperature geothermal weils $\left(<100^{\circ} \mathrm{C}\right)$ which enit two different phases, a water phas and a nitrogen gas phase. The gas phase is usually 22 , of the total voluse but it has 5 to 10 times higher radon activity. The short ter behavior of radon in a seismically inactive area has been investigated by twice weekly sampling of two wells in the city of Reykjavik for a period of three months. In a more active area the geographical variation of radon in wells and springs has been mapped in the Southern Iceland Seismic Zone (SISZ) and the Tjornes Fracture Zone (TFZ), both active transforn fault crossing populated areas in Iceland. Seven geothernal vells within the SISZ and two wells within the IFZ were chosen to study radon variations with time and to correlate observed varia tions with local earthquake activity. Weekly sampling has been in progress since January 1978. The largest earthquakes which have occurred during 1978 within the SISZ were 31 March, $M=3.3$; 3 July, $M=2.7$, 28 August, $M=3.5$. The event of 31 March occurred $5 \mathrm{~km}$ away from the closest sampling station but only minor changes in radon can be related to the event. The 3 July event was preceded by an anomaly showing fourfold increase in radon activity and a duration of 20 days at sampling station Fludir ( $321 \mathrm{~m}$ deep) $12 \mathrm{~km}$ away. Other sampling stations with much shallower wells located $6 \mathrm{~km}$ and $12 \mathrm{~km}$ from the epicenter of this event show only minor changes. A similar anomaly occurred at Fludir prior to the 28 August event.
T 126

GEOCHBMICAL RESEARCH RELATED TO EARTHQUAKE PREDICTION AT LAKE JOCASSEE, SOUTH CAROLINH

\section{Pradeep Talwani}

Jin Chiang (all at: Geology Dept., University of South Carolina, Columbia, S.C. 29208)

Continous low level seismic activity was found to occur at Lake Jocassee after the impoundment of the reservoir in 1975. In addition to modia series of geochemical measurements in an effor to search for precursors to $\mathrm{M}_{2} \sim 2-2,5$ events. Discrete water samples were collected from well and $a$ spring and their radon content was deterwined by scintillation counting. These data wer comparable to those obtained from a continuous ber. Soil $\mathrm{Rn}$ measurements in track-etch cups were started in 1977. Other geochemical measur ments included chlorinity, conductivity, and alkalinity of the water samples.

The results of the data collected so far indicate: (a) There are seasonal fluctuations in the radon concentrations in the spring, with a period of $\sim 46-47$ weeks, the radon content being 25
$40 \%, 1$ ower in summer. (b) Anomalous changes 40\% lower in summer. (b) Anomalous changes in after earthquakes. The timing of the anomaly was found to be dependent on the distance of the epicenter to the radon sample site. (c) Both high and 1 ow anowalous radon values were obtained. (d) The soil radon method was found to be useful in determining areas of high and low $\mathrm{Rn}$ concenin determining areas of high and low Rn concentrations, but not for a study of short term te-
poral changes. (e) Other geochenical measurements may provide clues to the depth to the ments may provide clues to

GEOCHEMICAL MEASUREMENTS PERTINENT TO SARTHQUAKE PREDICTION

Ta-1iang Teng (Department of Geological Los Angeles, California 90007)

Field groundwater sampling work started at U.S.C. in October, 1974, over an area along "locked" segment of the San Andreas fault fron Corman to San Bernardino. To date, an extensiye sampling network has been established over ige area with primarily regular weekly sampling from sites that include cld springs, hot springs, deep frrigation wells, and artesian wells. A year ago, we began frit the Siadon conteat of groundwater issutag the Pine Creek tungsten mine at the lnside of the Owens Valley. Data from these monitoring ef the owens Valley. Data from these monitor pursuing the development of a continuous groundwater radon monitoring system. Currently, through collaboration o through collaboration with Dr. Wakita (Japan) counting system has been operating in one of our counting system has been operating in one of our author recently returned from a trip to the People's Republic of China where he had a chance to examine a newly constructed continuous radon monitoring system. A report will be siven discussing the various characteristics of these different systems.

$-21$

INVESTIGATION OF RADON AND HELIUM AS POSSIBLE FLUID-PHASE PRECURSORS TO EARTHQUAKES

$\frac{\text { R. Poreda }}{\text { Y. Chung }}$

Y. Chung
J. E. Lupton

R. Horowitz

. Craig (all at: Scripps Institution of 0cear ography, UCSD, La Jolla, CA 92093)

Radon, helium, and other dissolved gases $\mathrm{N}_{2}, \mathrm{CH}_{4}$ ) in 25 thermal springs and wells alor s. California fault zones have been monitored since 1974 as part of the USCS Earthquake Hazarts Reduction program. In these thermal springs hellum, argon, and nitrogen variations in inditidual sites plot in linear arrays representiog too component mixtures. A "deep" component with excess $\mathrm{He}, \mathrm{Rn}, \mathrm{CH}_{4}$, and sometimes $\mathrm{N}_{2}$ mixes surface water of the spring containing essentially no $\mathrm{He}, \mathrm{Rn}$, or $\mathrm{CH}_{4}$, but equilibriuth $\mathrm{Con}$ trations of Ar and $\mathrm{N}_{2}$ corresponding to atmost
pheric solubilities at the spring temperatur. 